\title{
1. A legacy of discrimination
}

This book presents an exploration of sorts. We begin with a seemingly reasonable assumption: The cultural evolution of the United States has been intricately tied to its immigration history (i.e., the volume and timing of immigrant arrivals and their source countries/regions); and this history has been influenced by the country's immigration policies. Supporting this assumption, we note that prior to 1790, during the Colonial Era and the first years following independence, there were few laws that restricted the arrival of immigrants or that dictated the composition of immigrant inflows. Largely, an "open door" immigration policy was maintained and, from 1790 until 1875, a de facto policy was generally followed as immigration to the U.S. was influenced, in part, by restrictions on who could become a citizen. Since the Naturalization Act of 1790 specified that only "free white persons" who were "of good moral character" could become citizens, the lack of a cohesive immigrant policy coupled with restrictions on naturalization provided incentives for immigration from countries located in Northern and Western Europe while simultaneously serving to discourage immigration from other regions. ${ }^{1}$

Beginning in 1875, de jure federal legislation/policies further shaped immigration to the United States. The federal policies reaffirmed the entry preference that had been enjoyed by immigrants from Europe and discouraged or, in some cases, directly limited or banned immigration from many other locales. This persisted, largely unabated, until the second half of the twentieth century when the McCarran-Walter Act (1952) and the HartCeller Act (passed in 1965 and enacted in 1968) were implemented. The Hart-Celler Act led to a marked increase in the annual immigrant inflow as well as a corresponding shift in the primary source countries and regions for U.S. immigrant arrivals.

To a large degree, the current composition of American society, as indicated by self-reported ancestries, mirrors the nation's historic immigrant inflows. ${ }^{2}$ From 1840 through 1889, 14.3 million immigrants arrived in the United States. As noted, Europe was the primary source region of these arrivals, accounting for 89.1 percent of the inflow. More specifically, 11.7 million of the arrivals were from Northern and Western Europe, with Germany (29.9 percent of the total inflow), Ireland (22.4 percent), and the 
United Kingdom (18.1 percent) collectively accounting for 10.1 million arrivals. Between 1890 and 1919, another 18.2 million individuals migrated to the U.S. During this period, 88.4 percent of all arrivals were from Europe and another 4.6 percent were from Canada. Unlike earlier inflows, however, the primary source regions were Southern and Eastern Europe, with Italy (20.6 percent), Austria-Hungary (20.2 percent), and Russia and Poland (17.4 percent combined) accounting for 10.6 million of the total inflow. Given the large proportion of immigrants that arrived from Europe and the lengthy period during which this pattern of immigration persisted, it is not surprising that as of 1919 the U.S. population was predominantly European or of European descent.

Following passage of the Emergency Quota Act in 1921, immigrant inflows decreased and remained low relative to historical levels for a number of decades. When the Hart-Celler Act was enacted in 1968, U.S. immigration policy changed significantly. The act abolished the biased National Origins Quota System and established a preference system based primarily on family reunification, filling labor market vacancies, and admission of refugees and asylum-seekers. Since the implementation of the Hart-Celler Act, a shift in the primary source countries and regions of U.S. immigrant arrivals has been observed. Europe is no longer the dominant source region. It has been replaced by Asia, Latin America and the Caribbean, and, to a lesser extent, Africa. Even so, immigration from Europe left pronounced demographic and cultural imprints on the U.S. As evidence, over the 2009-2013 period, nearly a half-century since the implementation of the Hart-Celler Act, the American Community Study (ACS, 2015) found that 58 percent of U.S. residents self-identified as being of European ancestry.

During the past five decades, a total of 58.5 million immigrants entered the United States. Illustrative of the pronounced shift in source regions, Europe and Canada account for only 8.1 million of the total immigrant inflow (13.8 percent). The vast majority of these more recent immigrant arrivals have come from Latin America (50.8 percent) or Southern and Eastern Asia (25.2 percent). The primary source countries have been Mexico (with 27.8 percent of the total inflow), China (5.4 percent), and India (4.6 percent). These three countries have collectively accounted for 22.2 million of the total immigrant arrivals.

We contend that U.S. immigration policy has had a marked influence on immigrant arrivals both in terms of their numbers and their source countries/regions. Further, we make the case that the history of U.S. immigration policy is one of overt discrimination, prejudice, and bias wherein preference for immigrant arrivals from European nations was institutionalized. As a result, immigration policy influenced immigrant arrivals, 
which, in turn, influenced American culture such that the U.S. was, in the late 1960s, more culturally similar to Europe (particularly Northern and Western European countries) and Canada and Australia and New Zealand (as countries also settled by Europeans), and was more culturally dissimilar to societies in Asia, Latin America and the Caribbean, and Africa. Although we detail this history in subsequent chapters, in the next section we recount three events that are representative of the discrimination suffered by certain immigrant groups and that are illustrative of the prejudice and bias that has existed and which persists against immigrants and immigration.

\subsection{THREE REPRESENTATIVE EVENTS}

In 1875, an unskilled Chinese laborer named Chae Chan Ping arrived in San Francisco. In 1887, after having worked for twelve years in the U.S., he wished to visit his homeland. Prior to his departure, Chae Chan Ping obtained the proper paperwork to re-enter the U.S.; however, when he returned on October 8,1888 , even though he possessed the requisite re-entry certificate, Chae Chan Ping was detained on the ship on which he had arrived and was not allowed to enter the country. The basis for the detention and refusal of entry was that, in September 1888, the U.S. Congress had passed the Scott Act, an addendum to the Chinese Exclusion Act of 1882, and it had been signed into law on October 1, 1888 by President Grover Cleveland. In a few words, the Scott Act banned the reentry of Chinese laborers to the United States. In addition to Chae Chan Ping, the act affected another 20,000 to 30,000 Chinese laborers who were outside of the U.S. at the time it was signed into law and, thus, were unable to re-enter the country.

Chae Chan Ping challenged his detention and his case, which is perhaps better known as the Chinese Exclusion Case, eventually reached the U.S. Supreme Court. The Supreme Court ruled in favor of the United States on May 13, 1889 and, by doing so, set a legal precedent that afforded the political branches of government, and particularly the president, wide latitude in setting the nation's immigration policy. ${ }^{3}$ This latitude is commonly referred to as the "plenary power doctrine" and holds that, as a basic attribute of sovereignty, the power to regulate all aspects of immigration resides solely with the political branches (i.e., the executive and the legislative). Moreover, the Court's decision allowed the government to enact legislation that is contrary to existing international treaties. ${ }^{4}$

It may be convenient to view the refused re-entry of Chae Chan Ping and other Chinese laborers as isolated events or as historical remnants, 
as something that happened in the distant past, in a different time, so to speak. Unfortunately, this is not the case. Seven years prior to the passage of the Chinese Exclusion Act, the Page Act was passed by Congress and signed into law by President Ulysses S. Grant. The act, named for its sponsor, Representative Horace F. Page, was designed to "end the danger of cheap Chinese labor and immoral Chinese women" (Peffer, 1994, p. 29). Specifically, the law prohibited the entry of individuals from Asia who were coming to America as forced laborers, Asian woman who may engage in prostitution, and anyone considered to be a convict in their home country. Although it is true that a number of colonies and states enacted legislation prior to 1875 that was intended to govern immigrant inflows, the Page Act is often viewed as the first federal effort to limit immigration.

In the years following passage of the Scott Act of 1888, additional laws were enacted to further restrict immigration from China and additional legislation was passed to restrict immigrant inflows from other countries and regions. Typically, these restrictions sought to limit (or, in some instances, ban) immigration from countries other than those located in Northern or Western Europe. Coupled with these legislative attempts, there were numerous instances of discrimination, intimidation, and violence against immigrants. ${ }^{5}$ These anti-immigrant acts were sufficiently commonplace as to not be limited to a particular group or time period.

Nearly a decade after the U.S. Supreme Court ruled in the Chinese Exclusion Case, the Treaty of Paris was signed in 1898 to end the SpanishAmerican War. Per the terms of the treaty, the Philippines was ceded to the U.S. in exchange for $\$ 20$ million. The Philippines became a U.S. protectorate and remained as such until 1946. During this period there were no restrictions on Filipino migration to the U.S.; however, Filipinos in the U.S. were classified as "nationals" rather than "citizens" and, unless they had been born in the U.S., they were denied naturalization.

The economic prosperity of the 1920s left many farmers and ranchers in California facing a shortage of white labor. As a result, these employers turned to immigrant labor and during the decade nearly 30,000 male Filipino agricultural workers arrived in California (Starr, 1997). The vast majority of these men were unmarried and relatively young. To provide a sense of just how large the Filipino agricultural workforce was, by 1930 these workers accounted for nearly 20 percent of all farm workers in the state's north and central coasts and in the Sacramento and San Joaquin valleys (Starr, 1997).

Many white Americans who worked in California agriculture viewed the Filipino workers as competition, and many believed that the immigrant workers had been specifically recruited to place downward pressure on wages, to break strikes, and to counter the growing influence of labor 
unions (Reimers, 2005). Not surprisingly, anti-immigrant sentiment was fomented and, in a number of instances, violence resulted. The stock market crash in October 1929, the subsequent Great Depression, and the resulting economic hardships only served to heighten anti-immigrant feelings and the opposition to immigrant labor.

While it may seem reasonable to some that white American agricultural workers would oppose immigrant workers who they saw as competition, especially in light of the Depression, the opposition to Filipino farm workers was not limited to their native-born, white agricultural worker counterparts. Recall that Filipino farm workers were typically male and young. When they began to dance with white women in local dance halls or to date them, anti-Filipino sentiment was stirred within the white community in general, and especially among the white male population. A most succinct expression of this sentiment was reported in an editorial that ran in the San Francisco Chronicle. The Chronicle stated:

Our people are race-conscious to an abnormal degree. A violation of the race taboo arouses us more than a serious crime. And the first of race taboos is women. Racial aliens may undercut us, take away our jobs, surpass us in business competition, or commit crimes against our laws, and we would be only a little harder on them than we would be on aliens from Europe of our own race. But let them start to associate with our women and we see red. (in Baldoz, 2011, p. 144)

The above quote not only references sexual jealousy but also suggests that whites, in general, would treat Filipino immigrants differently from other whites or from European immigrants - specifically, the editorial notes that "we would be only a little harder on them." As evidence of how widespread this sentiment was, on January 7, 1930, the Northern Monterey County Chamber of Commerce cited "moral and sanitary" grounds in addition to a threat to white workers as the basis for its call to end the hiring of Filipinos. Specifically, the Chamber charged that: (1) Filipinos had increased the local labor supply and, thus, lowered wages for American workers; (2) some Filipinos had arrived suffering from meningitis and/or other diseases that could prove dangerous to the existing community; and (3) some Filipinos had married white women and that, if left unchecked, others would follow suit (Bogardus, 1930).

A front-page article in the January 10, 1930 Evening Pajaronian, a Watsonville, California newspaper, detailed the Chamber meeting and its call. On the topic of inter-marriage, the article provides the following quote: "If the present state of affairs continues there will be 40,000 halfbreeds in California before ten years have passed." The article also included racist comments made by Judge D.W. Rohrback of neighboring Monterey County, who referred to Filipino workers as "little brown men 
attired like Solomon in all his glory, only a decade removed from the bolo and the breechcloth" (Bogardus, 1930), "strutting like peacocks through the towns of the region to attract white and Mexican girls" (Starr, 1997). Another statement made by Judge Rohrback reads: "The worst part of [the Filipino man] being here is his mixing with young white girls from thirteen to seventeen. He gives them silk underwear and makes them pregnant and crowds whites out of jobs in the bargain" (Ngai, 2014).

Tensions heightened and, slightly more than one week later, antiFilipino demonstrations began in Watsonville on January 19, 1930. Over the course of the following three days, the demonstrations became violent riots, reaching a climax when several carloads of whites fired shots into a bunkhouse where Filipinos were said to have been sleeping. As soon as the first shots were fired, the startled Filipinos dropped to the floor or sought shelter in closets. Following the attack, it became apparent that Fermin Tobera, a 22-year-old, was dead, having been shot through the heart. In addition to the single death, another 60 individuals were injured during the riots (Fabros, 1996). That the demonstrations/riots were able to continue for nearly four days speaks to the extent of anti-Filipino sentiment in the community. Even so, an editorial in the January 24 edition of the Watsonville Register provided a description of the events while denouncing those involved in the riots:

It is anything but inspiring in this year of our Lord, 1930, to witness a mob of some 400 or 500 individuals attacking a dozen or so frightened Filipinos, rushing into their houses, dragging them out, beating them up, and then wrecking or damaging their domiciles. That is not Americanism. (Bogardus, 1930)

To gain perspective on how widespread the riots were, the 1930 census indicates that the population of Watsonville was only 8,344 persons (U.S. Census Bureau, 2017). If the news account of " 400 or 500 individuals" is accurate, then the mob was equivalent in size to 4.8-6 percent of the town's population (or the equivalent of about one in every 16 to 21 residents). Additionally, the riots were sufficiently notable as to have been reported in newspapers in the eastern U.S.; and, upon hearing of Tobera's death, a demonstration against perceived racialized violence was held at the University of the Philippines in Manila. News reports differ on the size of the demonstration, ranging from as few as 1,500 (reported in the New York Times) to more than 10,000 (as indicated in the Evening Pajaronian) (Bender and Lipman, 2015). As further evidence of the extent to which anti-Filipino sentiment existed elsewhere in California, in Stockton on January 29, 1930 a Filipino clubhouse was dynamited and, in the weeks that followed, anti-Filipino demonstrations were held in Salinas, San Francisco, and San José (Starr, 1997), while race riots broke out later the 
same year in the Imperial Valley and in Exeter (Bogardus, 1930). Elsewhere on the west coast, riots targeting Filipinos occurred in Washington state in Yakima (1928), Wenatchee Valley (1928), White River Valley (1930), and Wapatao (1934), and in Hood River and Banks, Oregon (1930) (Starr, 1997).

While the Philippines remained a protectorate of the U.S. until 1946, the Tydings-McDuffie Act was passed in 1934 to establish a process for the Philippines to become independent after a 10 -year transition period. It also reclassified Filipinos, including those who were already living in the U.S., as aliens. As a result, immigration from the Philippines to the U.S. became subject to the quota limits established by the Emergency Quota Act of 1921 and revised by the Johnson-Reed Act of 1924. In total, the annual quota for immigration from the Philippines to the U.S. was set at 50 persons; hence, the Tydings-McDuffie Act effectively halted Filipino immigration to the U.S. Additionally, in 1935, the Filipino Repatriation Act was passed which provided subsidized passage for U.S.-based Filipinos who wished to return to the Philippines (Schultz, et al., 2000). In combination, the acts had the effect of reducing/halting immigration to the U.S. from the Philippines while simultaneously seeking to reduce the size of the Filipino population in the U.S.

As with Chae Chan Ping and the Chinese Exclusion Case, there may be a temptation to view the treatment of Filipinos and the riots in Watsonville and other cities and towns in the western U.S. as relics from our past, as a shortlived aberration that is not representative of our views and norms, of who we are as a society. It is unfortunate that, nearly a full century after the events of January 1930 in Watsonville, on June 16, 2015, when declaring his candidacy for the Republican presidential nomination, Donald Trump stated:

When Mexico sends its people, they're not sending their best. They're sending people that have lots of problems, and they're bringing those problems. They're bringing drugs. They're bringing crime. They're rapists. And some, I assume, are good people. (Time, 2015)

Although this statement is shocking for its prejudice, ignorance, and outright racism, this was hardly Donald Trump's only racist, anti-immigrant statement. During the campaign for the Republican nomination, on November 22, 2015, Trump declared:

I want a database for the refugees that come into the country. We have no idea who these people are. When the Syrian refugees are going to start pouring into this country, we don't know if they're ISIS, we don't know if it's a Trojan horse. And I definitely want a database and other checks and balances. We want to go with watch lists. (ABC News, 2015) 
Earlier that same year, in a speech to the Iowa Freedom Summit, Trump asserted that half of the undocumented residents in America were criminals (LA Times, 2015). Still earlier, in 2013, while addressing the Conservative Political Action Conference, Trump stated that Congressional Republicans should oppose any form of amnesty for undocumented immigrants, but should seek to expand legal immigration from European nations (CPAC, 2013). A final example of Trump's anti-immigrant views came on September 16, 2015 when he said, "We have to have assimilation-to have a country, we have to have assimilation. I'm not the first one to say this. We've had many people over the years, for many, many years, saying the same thing. This is a country where we speak English, not Spanish" (American Presidency Project, 2015).

The bigoted views of Donald Trump and his anti-immigrant rhetoric (unless the immigrants are European) struck a chord with a large share of the American public and with many voters during the Republican Party presidential primaries and the 2016 Presidential campaign. In fact, one may argue that such views have now been normalized. Evidence of this is found in a report from the Southern Poverty Law Center which noted there was a sharp rise in the number of bias incidents immediately following the November 2016 election.

In the immediate aftermath of Election Day, a wave of hate crimes and lesser hate incidents swept the country-1,094 bias incidents in the first 34 days, according to a count by the Southern Poverty Law Center (SPLC). The hate was clearly tied directly to Trump's victory. The highest count came on the first day after the election, with the numbers diminishing steadily after that. And more than a third of the incidents directly referenced either Trump, his "Make America Great Again" slogan, or his infamous remarks about grabbing women by the genitals. (Potok, 2017)

Potok asserts that the popularity of Donald Trump and the postelection rise in bias incidents follow from long-developing trends, citing the increased share of the population accounted for by immigrants - a rise from 4.7 percent in 1970 to nearly 14 percent in 2015-and the corresponding decline in the white, non-Hispanic share of the U.S. population from about 90 percent in the 1960 s to 62 percent in 2015 .

The seeming backlash against shifting demographics is reflected in the results of the 2015 American Trends Panel Survey (Pew, 2015). One survey question that respondents were asked was "Do you think the impact of immigrants from [Europe, Latin America, Africa, Asia, Middle East; RANDOMIZED] on American society has been mostly positive, mostly negative, or neither positive nor negative?" The results are summarized in Figure 1.1. Regions are ranked, from left to right, in descending order by 


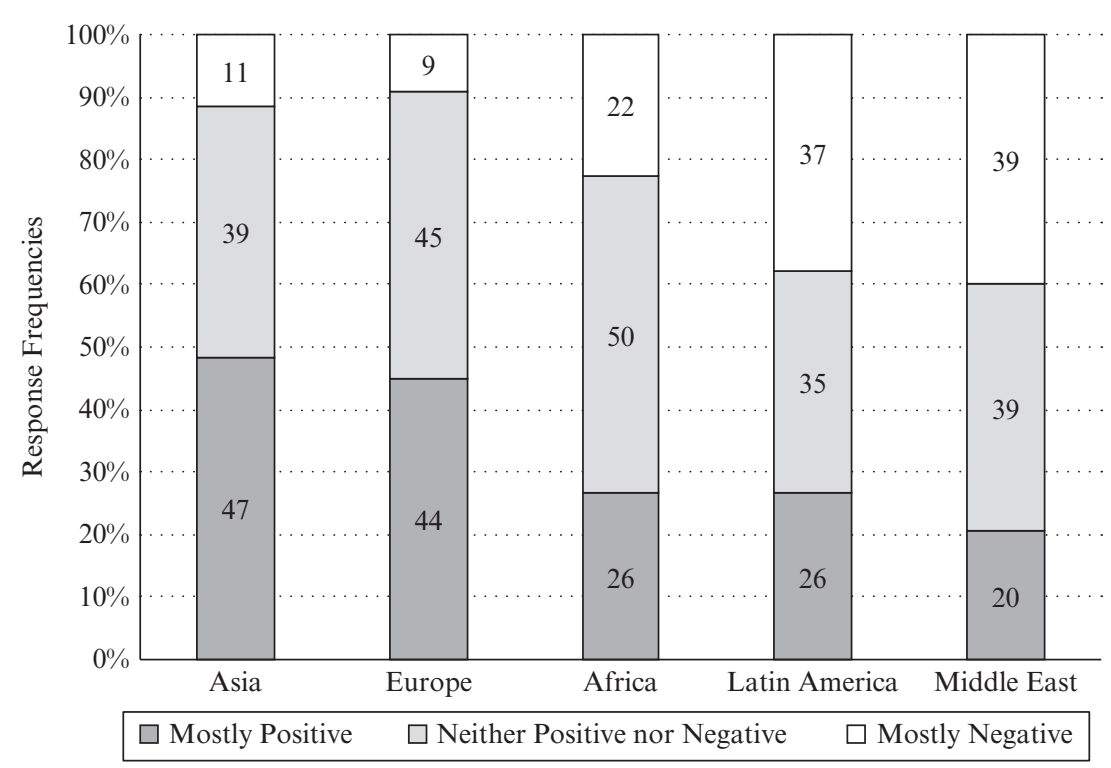

Figure 1.1 Do you think the impact of immigrants from [Europe, Latin America, Africa, Asia, the Middle East] on American society has been mostly positive, mostly negative, or neither positive nor negative?

the percentage of respondents who answered "mostly positive." We see that a higher percentage of survey respondents believed that immigrants from Asia, Europe, and Africa have a mostly positive effect on American society as compared to a mostly negative effect. To the contrary, immigrants from Latin America and the Middle East are viewed more frequently to have a mostly negative effect on American society rather than a mostly positive effect.

A large majority of respondents to the Pew survey (76 percent) agreed with the statement that adult immigrants in the U.S. need to learn English to succeed. Even so, 59 percent of the respondents held the opinion that recent immigrants do not learn English within a reasonable amount of time. These results, taken with the comments of Donald Trump and his subsequent election as president of the country, suggest that there is a significant bias among the U.S. population against immigrants from the Middle East or Latin America and the Caribbean, and against those who possess limited English-language skills.

The Pew survey also asked respondents "What ONE word comes to mind first when you think about immigrants in the United States today?" 
Table 1.1 What ONE word comes to mind first when you think about immigrants in the United States today?

\begin{tabular}{lc}
\hline Response & Frequency (\%) \\
\hline Illegal & 12 \\
Overpopulation/Lots/Many/Overwhelming & 5 \\
Legality (other than "illegal") & 4 \\
Jobs & 3 \\
Deportation/Go home/Restrict & 3 \\
People/Myself/My family/Americans/Everyone & 3 \\
Work ethic & 3 \\
Freedom & 3 \\
Hispanics/Mexico/Mexicans & 2 \\
Costs/Freeloaders/Burden/Debt & 2 \\
Fairness/Unfair & 2 \\
Opportunity & 2 \\
Workers/Labor & 2 \\
General/other, positive & 12 \\
General/other, negative & 11 \\
General/other, neutral & 26 \\
No answer/Uncodable & 6 \\
\hline
\end{tabular}

Responses are summarized in Table 1.1. The most common single word is "Illegal," being reported by nearly one in every eight respondents; 5 percent of the responses were categorized within the "Overpopulation/Lots/ Many/Overwhelming" grouping, while "Deportation/Go home/Restrict" accounted for 3 percent of responses and "Costs/Freeloaders/Burden/ Debt" was offered by another 2 percent of respondents. Lastly, 11 percent of responses were categorized as "General/other, negative." Thus, a full one-third of those surveyed offered a negative word when asked what they first think of immigrants in the U.S. today. If we exclude those responses that were classified as "No answer/uncodable" (6 percent) or as "General/ other, neutral" (26 percent) and assume that all other responses carried positive connotations, we have 33 percent offering a negative response and 35 percent offering a positive response - surprisingly, a quite even split.

On January 27, 2017, just six days after being inaugurated as President of the United States, Donald Trump signed Executive Order 13769, more commonly known as the "Muslim Ban." The Executive Order halted all refugee admissions for 120 days, suspended the entry of refugees from Syria indefinitely, and reduced the number of refugees to be admitted to the U.S. from 120,000 to 50,000 during the calendar year 2017 (DHS, 2017). The order also directed cabinet secretaries to suspend the entry of individuals from 


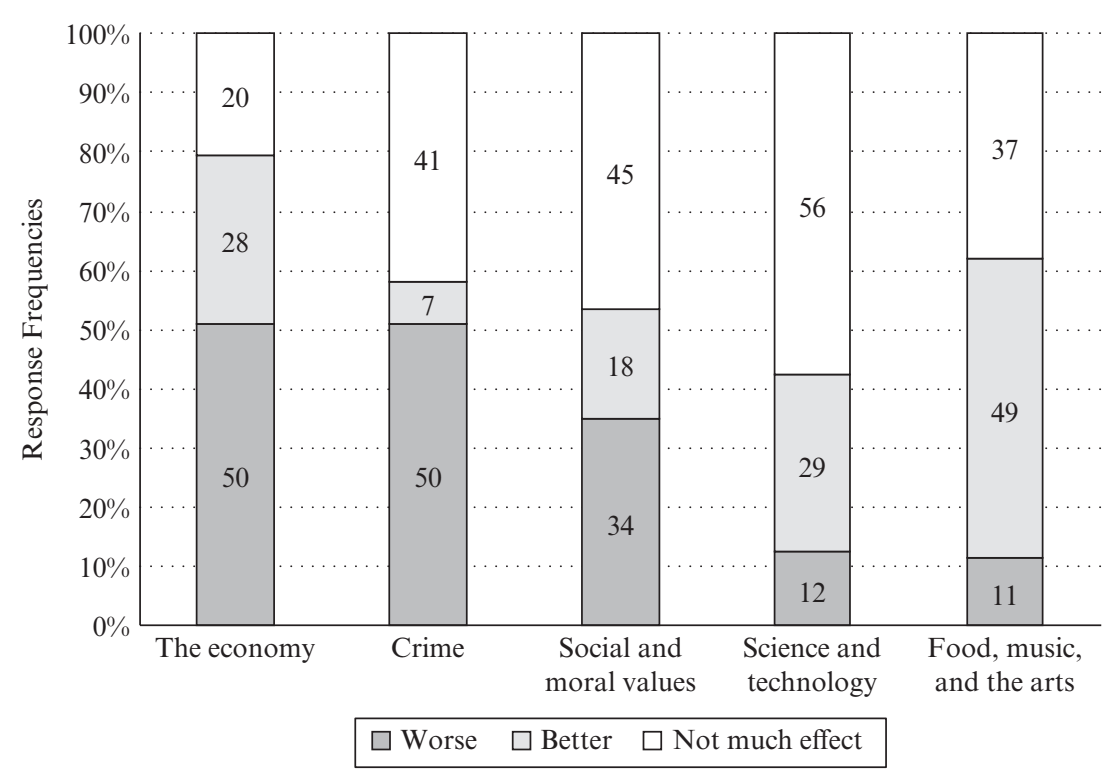

Note: Values here and in Figure 1.3 do not sum to 100 as respondents who did not answer the question are not shown.

Figure 1.2 Do you think immigrants in the United States are making things better, worse, or not having much effect in each of the following areas?

seven predominantly Muslim countries (i.e., Iran, Iraq, Libya, Somalia, Sudan, Syria, and Yemen) for 90 days. These countries were said to not meet adjudication standards for visa issuance under U.S. immigration law.

In response to the Executive Order, protests erupted in major cities across the U.S. and in some foreign cities (e.g., Berlin, London, and Glasgow), and on February 3 a temporary restraining order against the ban was issued by the Ninth Circuit U.S. Court of Appeals. On March 6, 2017, Donald Trump signed Executive Order 13780, commonly referred to as "Muslim Ban 2.0," which revoked and replaced Executive Order 13769 as of March 16, 2017. The two Executive Orders were quite similar-so much so that, one day prior to becoming effective, two District Courts issued temporary restraining orders against the revised ban. Collectively, the comments made by Trump, the survey responses, and the Executive Orders portray an anti-immigrant bias that echoes past prejudices and that mirrors the discrimination witnessed in earlier periods.

As evidence of the extent to which the American public views immi- 


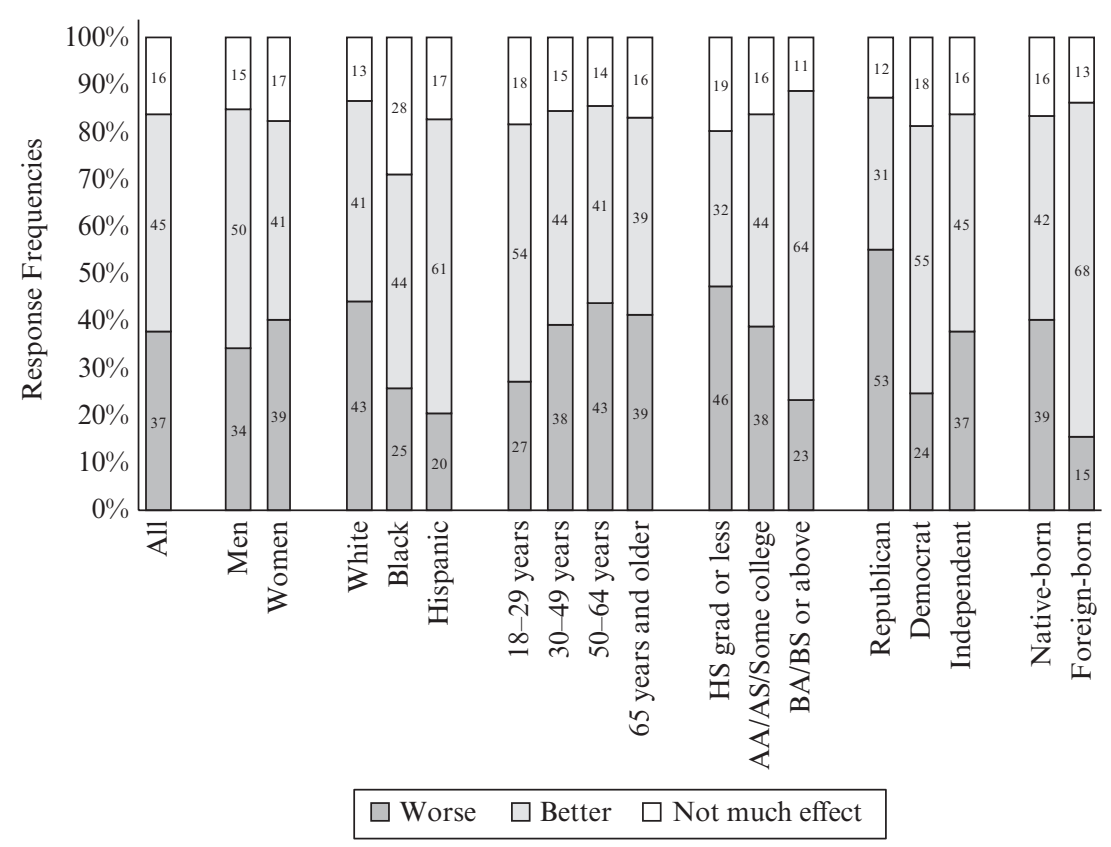

Figure 1.3 Generally, do you think immigrants coming to the United States make American society better in the long run, make American society worse in the long run, or don't have much of an effect on American society one way or the other?

grants negatively, the 2015 American Trends Panel survey (Pew, 2015) asked respondents whether they believe that immigrants in the U.S. improve, worsen, or do not much affect a number of topics. The results are illustrated in Figure 1.2. We see that survey respondents are considerably more likely to believe that immigrants have a detrimental effect on the economy, are the cause of more crime, and weaken social and moral values than hold the view that immigrants have positive influences on these topics. A majority of respondents do not see immigrants as having any significant influence on science and technology. It is only with respect to the topic of food, music, and the arts that we see a plurality of respondents sharing the view that immigrants have a positive effect.

When asked for their views of the long-run influence of immigrants on American society, a slight plurality of all respondents (45 percent) indicate they believe immigrants are beneficial to society. Men appear more likely than women to express positive views of immigrants. Hispanic respondents are much more likely to express a positive view. In fact, 


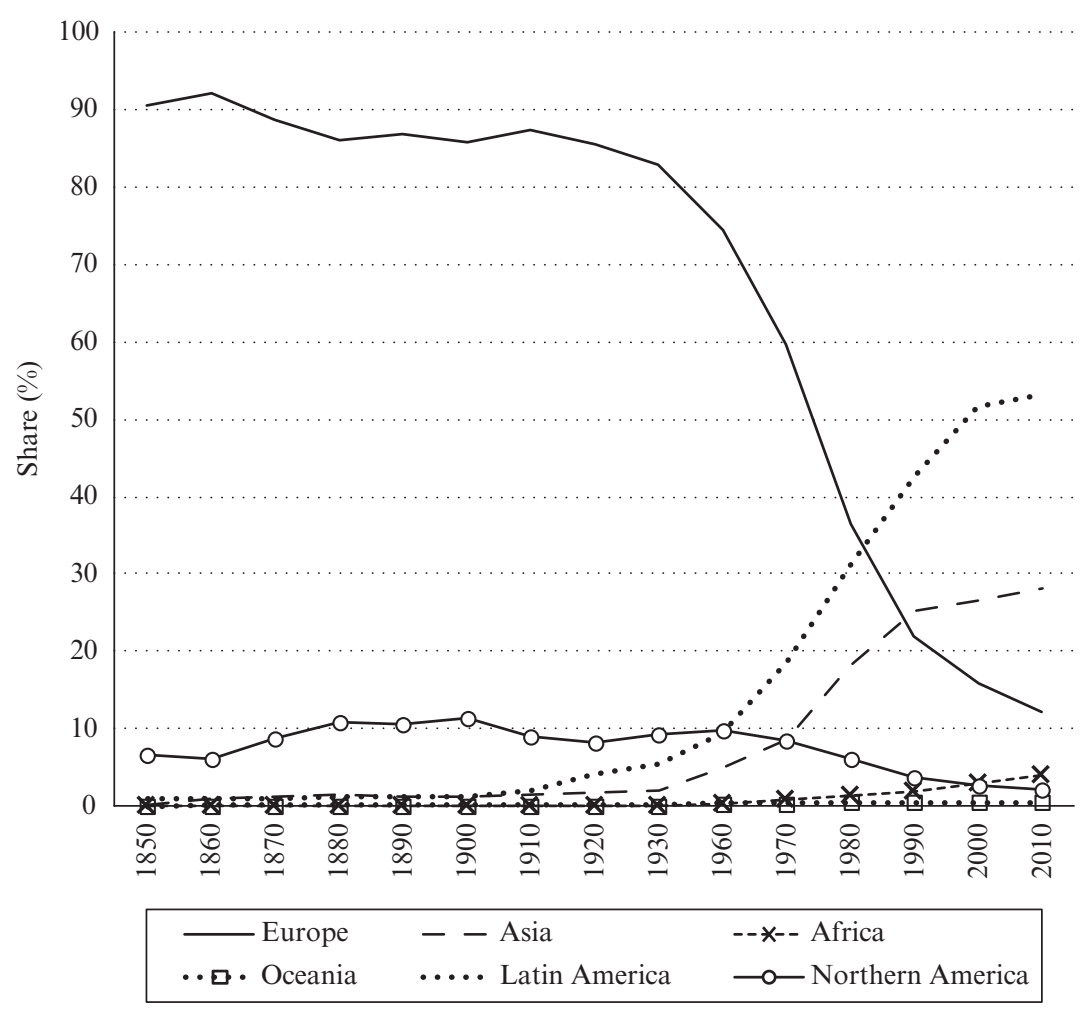

Source: Gibson and Jung (2007) for all years except 2010 (U.S. Census, 2017).

Figure 1.4 Region of birth of the foreign-born population of the U.S., 1850-1930 and 1960-2010 (\%)

whites are more likely to answer that immigrants make society worse (43 percent) than better (41 percent). Younger individuals are more likely to express the opinion that immigrants make American society better off in the long run. The same applies for more educated individuals. There is a clear split across political party affiliations, with respondents who selfidentify as Republicans being more likely to view immigrants negatively while Democrats and independents are both more likely to hold positive views of immigrants. Finally, not surprisingly, foreign-born individuals are much more likely than are the native-born to express a positive opinion of immigrants. These results are presented in Figure 1.3.

The preference afforded to immigrants from Europe, and primarily to those from countries located in Northern or Western Europe, may 
Table 1.2 World region of birth of the foreign-born population of the U.S.: 1850 to 1930 and 1960 to 2010 (thousands)

\begin{tabular}{rrrrrrrrr}
\hline Year & Total & Europe & Asia & Africa & Oceania & $\begin{array}{c}\text { Latin } \\
\text { America }\end{array}$ & $\begin{array}{c}\text { Northern } \\
\text { America }\end{array}$ & $\begin{array}{c}\text { Not } \\
\text { Reported }\end{array}$ \\
\hline 2010 & 39,956 & 4,817 & 11,284 & 1,607 & 217 & 21,224 & 807 &. \\
2000 & 31,108 & 4,916 & 8,226 & 881 & 168 & 16,087 & 829 & 0 \\
1990 & 19,767 & 4,350 & 4,979 & 364 & 104 & 8,408 & 754 & 808 \\
1980 & 14,080 & 5,150 & 2,540 & 200 & 78 & 4,372 & 853 & 887 \\
1970 & 9,619 & 5,741 & 825 & 80 & 41 & 1,804 & 812 & 316 \\
1960 & 9,738 & 7,256 & 491 & 35 & 35 & 908 & 953 & 60 \\
1930 & 14,204 & 11,784 & 276 & 18 & 17 & 792 & 1,310 & 7 \\
1920 & 13,921 & 11,916 & 238 & 16 & 15 & 589 & 1,138 & 9 \\
1910 & 13,516 & 11,810 & 191 & 4 & 11 & 280 & 1,210 & 10 \\
1900 & 10,341 & 8,882 & 120 & 3 & 9 & 137 & 1,180 & 11 \\
1890 & 9,250 & 8,030 & 113 & 2 & 9 & 107 & 981 & 6 \\
1880 & 6,680 & 5,752 & 108 & 2 & 7 & 90 & 717 & 4 \\
1870 & 5,567 & 4,941 & 65 & 3 & 4 & 58 & 493 & 4 \\
1860 & 4,139 & 3,807 & 37 & 1 & 2 & 38 & 250 & 4 \\
1850 & 2,245 & 2,032 & 1 & 1 & 1 & 21 & 148 & 42 \\
\hline
\end{tabular}

Source: Gibson and Jung (2007) for all years except 2010 (U.S. Census, 2017).

explain both the past incidents that are discussed earlier in this section and the survey results that are summarized above. Figure 1.4 illustrates the shares of the foreign-born population of the U.S., by decade, from 1850 through 2010, while Table 1.2 provides a summary of the total foreign-born population of the U.S. for each source region during the 1850-2010 period.

There are several interesting relationships presented in Figure 1.4. First, we see that the source region composition of America's foreign-born population remained largely stable until about 1920 . During this period, we also see that, from 1850 until 1920, immigrants from Europe accounted for 85-92 percent of the total foreign-born population. In 1920, we begin to see a slight increase in the share of immigrants from Latin America and the Caribbean. Although this trend persists and we also see an increase in the share of the foreign-born population from Asia, in 1960 immigrants from Europe still accounted for 74.5 percent of the foreign-born population. Over the past half-century, however, the share of immigrants from Europe has steadily declined, reaching 12.1 percent in 2010, while the shares of immigrants from all other regions, with the exception of Northern America, have risen. In fact, during the early and late 1980s, respectively, 
the share of America's foreign-born population that was accounted for by immigrants from Latin America and the Caribbean and from Asia exceeded the share from Europe for the first time in history.

We argue that the predominance and persistence of Europeans as a share of the U.S. foreign-born population influenced U.S. culture such that it developed to be more akin to the cultures of immigrant source countries in Europe. The recent influx of immigrants from Latin America and the Caribbean, Asia, and Africa has arrived to find a destination/host country that is culturally dissimilar from their source/home countries. Moreover, those already within the U.S. - especially the native-born - may view more recent immigrant arrivals (e.g., Mexican immigrants) similar to how the Chinese were viewed in the 1870 s and 1880 s or how Filipinos were viewed during the 1920s and 1930s. That is, we repeatedly see that many individuals view immigrants who are different from the dominant racial and/ or ethnic group(s) as somehow being threatening or as more likely to exert a negative influence on American society.

\subsection{A BRIEF ROAD MAP AND AN EXPLANATION}

Before we move ahead, while we have introduced our topic and, in very general terms, have provided context for the material that follows, it is worth providing some detail of what follows.

In the first part of this book, which spans Chapters 2 through 5, we provide a summary/review of the history of U.S. immigration and immigration policy and the corresponding influences it has had on the demographic composition of the nation's population. More specifically, Chapter 2 recounts the period from the founding of the Jamestown Colony in 1607 through 1874. Chapter 3 reviews the years from 1875 through 1920, a period during which qualitative restrictions on immigration were imposed. The focus of Chapter 4 is the period during which the U.S. maintained qualitative restrictions on immigrant inflows while also imposing quantitative limits - the National Origins Quota System period (1921-1967) — and Chapter 5 discusses the period since 1968.

The second part of the book, which includes Chapters 6 through 8 , presents our empirical analysis. In Chapter 6, we introduce the gravity model of international migration as the basis for our econometric model. In Chapter 7, we extend our analysis to consider whether key changes in U.S. immigration policy correspond with significant changes in the level of immigrant inflows and/or the composition of inflows in terms of country or region of origin. Finally, in Chapter 8 we address the questions of whether U.S. culture is more similar to the cultures of European countries 
as compared to the cultures of less-traditional source countries. Similarly, we consider whether changes in the levels of immigrant arrivals and the primary source countries of immigrants to the U.S. since the enactment of the Hart-Celler Act have led U.S. culture to become, in recent decades, less similar to European source countries and more similar to the cultures of less-traditional source countries.

The final section of our book begins in Chapter 9 with a discussion of the results presented in Chapters 6 through 8 . We follow this by considering population projections through 2065 . From these projections, a range of potential outcomes, in terms of the future evolution of U.S. culture, are presented. We close the book with Chapter 10, which presents a summary of the entire work and ends with a discussion of the implications of our results and the opportunities available to policy makers who seek to maximize the net social benefits of immigration.

It is important to note that, while the focus of this work is on the influence of U.S. immigration policy on the nation's culture, we would be remiss if we were to assume that the cultural evolution of the United States is solely the product of immigration policy. The institution of slavery, the treatment of indigenous peoples, Japanese internment, the Civil Rights struggles, and many other events and policies have contributed significantly to the shaping of the demographics of America's population and the evolution of American culture. Accordingly, we acknowledge that immigration policy is an incomplete explanation for the development and evolution of American culture. Even so, we cannot ignore that immigration policy has had a pronounced influence on the peopling of the United States and, thus, has had an influence on American culture and therefore, we contend, is a valid focal point for the work presented here.

\section{NOTES}

1. The Citizenship Clause of the 14th Amendment to the U.S. Constitution, ratified in 1868, states that "All persons born or naturalized in the United States, and subject to the jurisdiction thereof, are citizens of the United States and of the State wherein they reside" - thus extending birthright citizenship, with few exceptions, to all born in the U.S., regardless of race or the citizenship status of their parents.

2. The statistics presented in this chapter, unless otherwise noted, are calculated using data from the Pew Research Center (2015).

3. A somewhat similar instance involved Chew Heong, who had departed the U.S. for China prior to the passage of the Chinese Exclusion Act. When he returned, he did not have the re-entry permit that was mandated by an 1884 amendment to the act. Chew Heong would have been able to re-enter under the legal regime as it existed at the time of departure, which was shaped by the Burlingame-Seward Treaty (1868) and the Treaty Regulating Immigration from China (1880). When he was denied re-entry into the United States, he contested the decision and the U.S. Supreme Court decided in his favor. 
4. In this instance, the Scott Act of 1888 was contrary to the Burlingame-Seward Treaty (1868), which amended the Treaty of Tientsin (1858) to protect China from foreign interference in its affairs and to ease restrictions on immigration between the U.S. and China.

5. Arnold (2011) provides a comprehensive accounting of anti-immigrant violence in the United States. 
Roger White - 9781786435286

Downloaded from PubFactory at 04/26/2023 05:19:56AM via free access 